\title{
SOPHIA
}

PEER REVIEW JOURNAL

VISUAL SPACES OF CHANGE: UNVEILING THE PUBLICNESS OF URBAN SPACE

THROUGH PHOTOGRAPHY AND IMAGE

ISSN: 2183-8976 [PRINT] 2183-9468 [ONLINE]

Volume 4, Issue 1| Publication year: 2019

DOI 10.24840/2183-8976_2019-0004_0001_10

(c) SCOPIO EDITIONS

HOMEPAGE: HTTPS://WWW.SOPHIAJOURNAL.NET

\section{A BRIDGE}

Written by Sebastiano Raimondo

Translation from Portuguese to English by Gabriel Paixão

"... To travel? To travel it only takes to exist....

If I imagine, I see. What else do I do if I travel?

Only the extreme feebleness of imagination justifies the need to dislocate in order to feel. ...

... In reality, the end of the world, as the beginning, is our own concept of world. It is in us where landscapes have landscape.

For this, if I imagine them, I make them; if I make them, they are; if they are, I see them like I do to others. Travel for what? ...

... where would I be if not within myself, within type and style of my sensations?

Life is what we make of it. e travels are the travellers. What we see is not what we see, but what we are..."1

\section{Taking Place}

A Bridge continues my research initiated in 2007 when my photography studies at the Palermo University began. On the first project concluded in 2009, shortly after being transferred to Lisbon and beginning to work on the project which I named A Bridge, I faced photography as a window through which to look at the world in search of images that built my idea of landscape. Window or interstice from the Latin Fenestra whose Indo-European root pha(n) means splendour or glow, it's literally an opening to embrace the light; the same root is found in the word Epiphany whose meaning is divine manifestation.

\footnotetext{
1 Fernando Pessoa, Livro do desassossego por Bernardo Soares (Vol. 2) (Lisboa: Ática, 1982), p.132.
} 
I have learned to use photography as a way of thinking through images, in a path that goes from reality to representation or, in the opposite way, from this representation to the represented objects ${ }^{2}$. Through such, I have gotten to a possible conclusion in which what shows itself (instead of demonstrating) is the very method of utilizing photography. The possibility of this method being a way of bringing to light, of revealing meaning, order, and personal measure, but also stating that the gaze is guided by the external world in its representations or in what its places evoke. Today I wonder: who is the beholder behind that window? Isn't it the world itself looking at the world? ${ }^{3}$ Fernando Pessoa's quote at the beginning of this text was one of the reasons that led me to continue my studies, as well as living, in Lisbon. I could have worked in other cities, Palermo for example, but I believe that working in the actual city requires supplementary effort and sacrifice, courage to look in the mirror, especially because, as Fernando Pessoa suggests, we ourselves are the city even before photographing it. We would need inner work, dusting off and scraping our gazes, until finally being able to see ourselves better. Another fundamental reason is that our hometowns, the ones we were born in, are made of places filled with public and private history, where we may only travel around a time spectrum that is not the present, whose distance from could sharpen our pain, but also our gaze ${ }^{4}$. I will have probably already begun and am certain that each attempt to settle in a new city brings along pieces of personal roots. Curiously over these past years when I return to my hometown, some new question always befalls me, some which before I felt no need to place upon myself, question that requires proper sedimentation so that it slowly gains strength to rise.

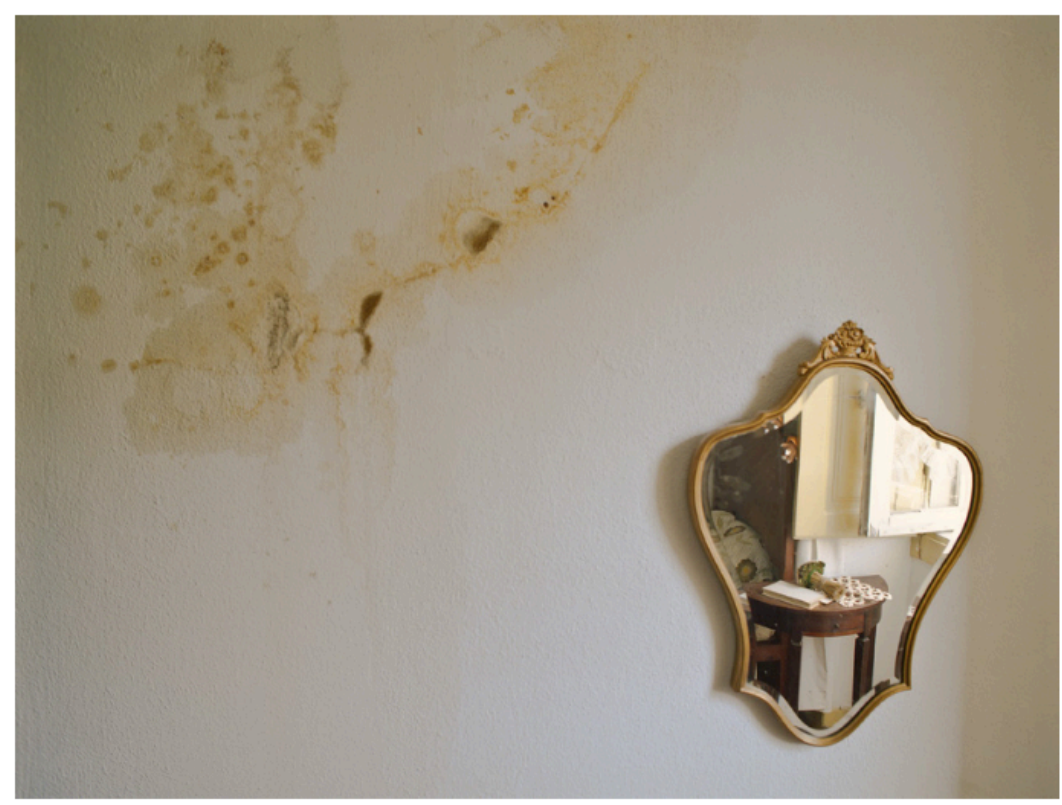

SEBASTIANO RAIMONDO

"01_031-32" from the series "Uma Ponte", 2009-2010

\footnotetext{
2 Mario De Caro \& Maurizio Ferraris, Bentornata realtà - il nuovo realismo in discussione (Torino: Giulio Einaudi Editore, 2012), p.148, 195.

Fernando Gil, Enciclopedia Einaudi (Vol. XI) (Torino: Einaudi, 1980), p.546.

Franco Purini, Comporre l'architettura (Roma, Bari: Gius. Laterza \& filgi, 2000), pp.94-97. De Caro \& Ferraris, 2012, p.148, p.95.

3 Italo Calvino, Palomar (Milano: Arnoldo Mondadori Editore, 1994).

4 Walter Benjamin, Immagini di città (Torino: Giulio Einaudi Editore, 2007), p.125.
} 


\section{Coincidence, Epiphany and Window}

Throughout the years in which I experienced Lisbon working on this project, I had no certainty of having known it authentically, nor was that a priority. Once returned to Italy, while revealing the films, making a first selection and printing some of these photographs, I realized something concrete had faced me, and in a different manner. There was a sequence of photographs that gathered my written notes, my drawings, and my memory. The camera, its use and all that was behind taking the photograph irremediably transformed the observed objects as well as my way of imagining what was in front of me. I don't deny having pleasurably favoured the coincidences, a "hic et nunc" ${ }^{\prime \prime}$, to which I necessarily adhered, driven by a curiosity of experiencing the departure from Palermo and what to do after arriving in Lisbon.



SEBASTIANO RAIMONDO

"02_046" from the series "Uma Ponte", 2009-2010

On the first notes, in 2009, I have written, in Joyce's manner, that all was an epiphany, an intuition that took back to a long buried recollection. Wim Wenders' cinema has certainly played a key role: when I attended Palermo University, "Lisbon Story"6 was the first film, and "Palermo Shooting"7 the last one to be seen before leaving to Portugal. These two films, among others of Wenders, face in quite evident way the theme of building the city's image and the image's capacity of evoking a narrative, without being necessary to write a script before shooting the film or staging unreal plays to fit sequences of photographs.

\footnotetext{
5 Walter Benjamin, L'opera d'arte nell'era della sua riproducibilità tecnica - Arte e società di massa (italiana ed.). (E. Filippini, Trad.) (Torino: Giulio Einaudi Editore, 2000), p.22, pp.62-63.

6 Lisbon Story. Film. Directed by Wim Wenders. Alemanha, Portugal, 1994.

7 Palermo Shooting. Film. Directed by Wim Wenders. Alemanha, França, Itália, 2008.
} 


\section{Analogy}

This is a way of looking at the city in the sequentially organized images, which can be seen whenever and wherever wished, being an analogous city. I wouldn't like for the images to be confused with reality, or with each one's personal experience; l'd simply say that this analogy between the city and the sequence of photographs is an interpretation, such as others necessary to orient us in the world, they may take each beholder to compare their own correspondences with the presented city. The meaning of "analogy" in photography refers to the fact of a photograph being a trait of reality, real on itself for there was physical contact between them, but reality, such as a tale made of a sequence of photographs, is evidently more complex. This case is interested in another idea that the architect Aldo Rossi explains as being the phases of a process: when we look at a place we only see its result, a sum of facts that require analysis ${ }^{16}$. Analogous to the architecture project which, even though made out of something that stands over time, is formed by continuous small variations whose first ratio, in photography the contact with reality, is always farther and continuously subject to variations in future times.

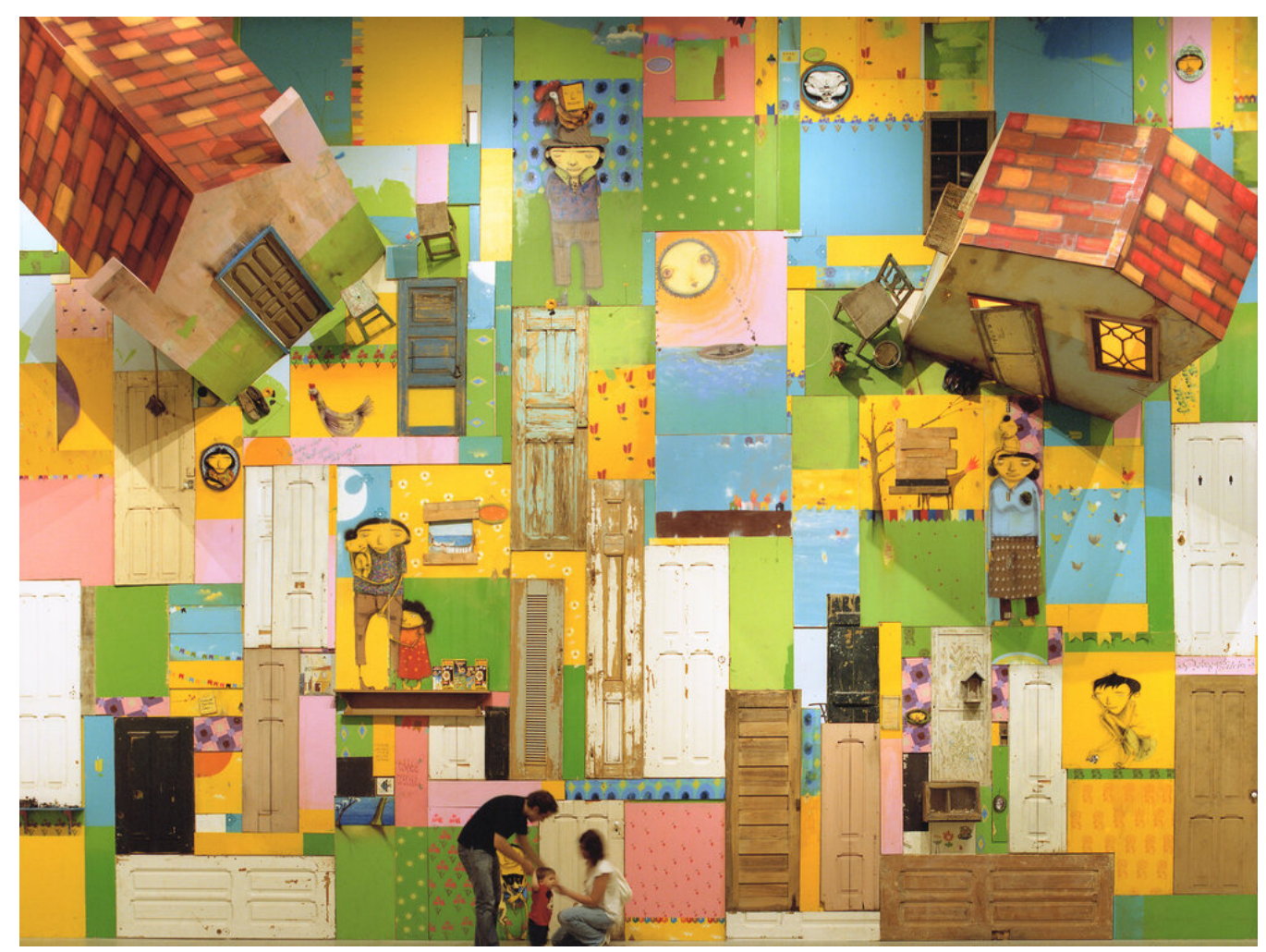

SEBASTIANO RAIMONDO

"12_229 expo os gémeos CCB" from the series "Uma Ponte", 2009-2010

Aldo Rossi insists that it isn't incorrect to explain all of this with the word love, which also behaves as something inexplicable or unpredictable, because this small and compassionate blindness allows the representation to build a bridge between past and present ${ }^{17}$, which for me are the fragment of time and a particular spatial relation, both kept within the images

\footnotetext{
16 Aldo Rossi, Autobiografia scientifica (Milano: Il saggiatore, 2009), pp.104-120.

17 Aldo Rossi, Autobiografia scientifica (Milano: Il saggiatore, 2009), p.105.
} 
which repeat themselves each time we look at photographs or places. In another manner Luigi Ghirri, when he says that images are "riddles to be solved with the heart"18 and that this "thought is speculation through images"19 quoting Giordano Bruno, is able to unite the philosophical dimension with the one of photography's nature, whose mirror potency is in the very optical construction of any lens, today in ordinary cell phones, formerly in the first cameras.

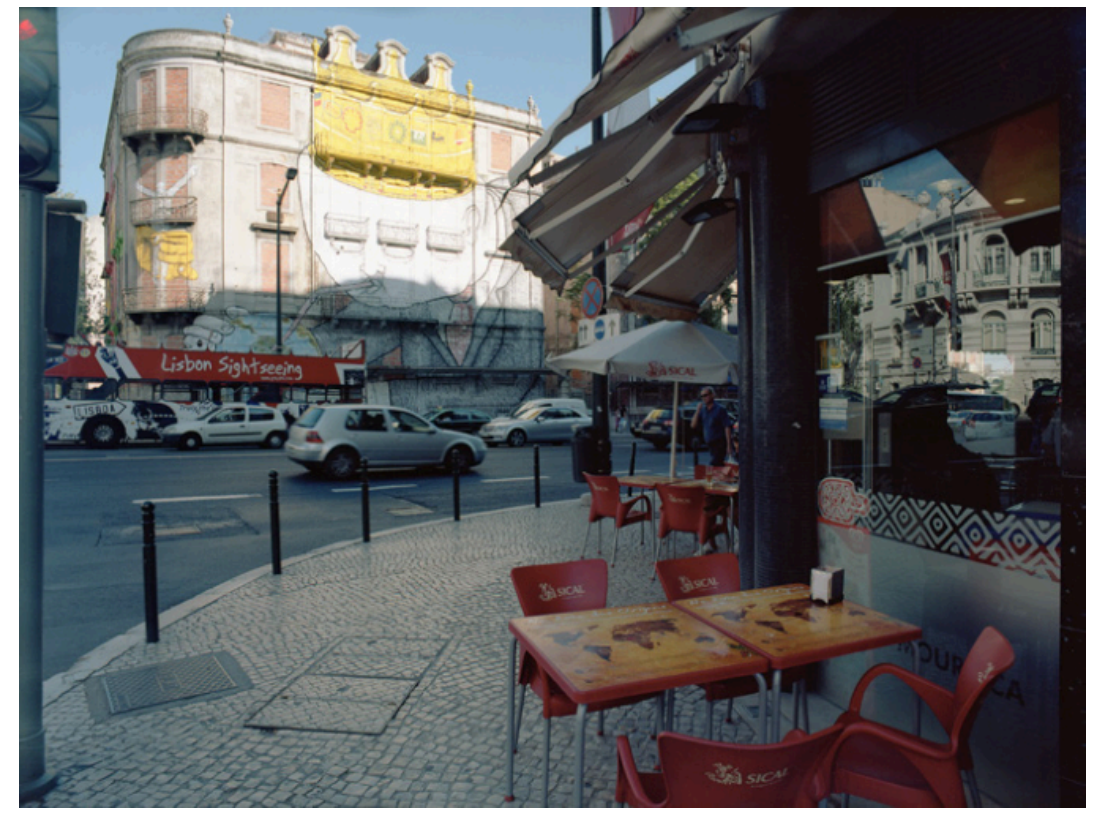

SEBASTIANO RAIMONDO

"12_206 expo os gémeos CCB" from the series "Uma Ponte", 2009-2010

\section{An Answer from Looking}

Stemming from these places I haven't found any answers to the questions, already placed by great landscape photographers ${ }^{20}$, but an umpteenth reflexion regarding the mission of photography as a vehicle capable of transmitting the image of the world.

"Looking is not seeing"21, says the Italian philosopher Silvano Petrosino, and the place of the experience of light at the end is the manifestation of my own gaze, an answer that turns the city into a set made of all gazes that tried to host something perceived. The photographs, "in" and not "upon" the city of Lisbon, were taken in between things and do not wish to impose any gaze, they allow the presence of what is in the image's margins and what escapes the machine's control. In this sense, to me the photographer's gaze tries to guard, in a way that it embraces these images, knowing that by doing so it will allow its transmission.

\footnotetext{
18 Luigi Ghirri, Niente di antico sotto il sole. (G. Chiaramonte, \& P. Constantini, A cura di) (Torino: Società Editrice Internazionale, 1997), p.155.

19 Francesca Fabiani \& Laura Gasparini \& Giuliano Sergio, Luigi Ghirri - Pensare per immagini - Icone Paesaggi Architetture (Milano: Mondadori, Electa, 2013), p.54.

20 Matteo Balduzzi \& Antonello Frongia \& William Guerrieri \& Roberto Valtorta, Luogo e identità nella fotografia italiana contemporanea. (R. Valtorta, A cura di) (Torino: Giulio Einaudi Editore, 2013), p.16, p.58.

21 Silvano Petrosino, Piccola metafisica della luce (Milano: Editoriale Jaca Book, 2004), p.49.
} 


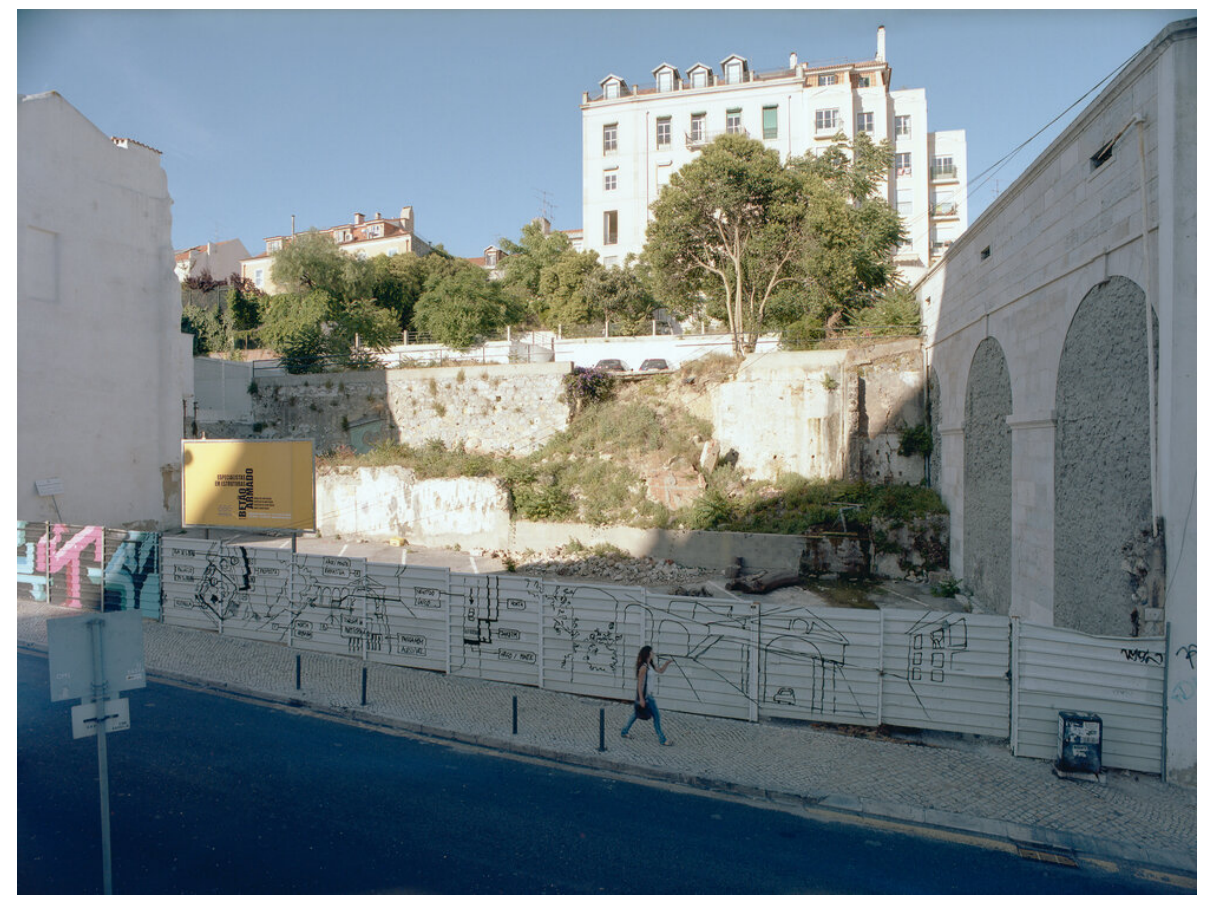

SEBASTIANO RAIMONDO

"11_197" from the series "Uma Ponte", 2009-2010

This mission is a way of inhabiting and being in the world, it's an answer given through looking. e verb to look, in Italian guardare, corresponds to the etymological meaning of guarding, in Portuguese, which is different than immediate looking: it speaks of the guardian who cares about an object, place or person. As so, the gaze's answer is a way of managing these thing $\mathrm{s}^{22}$, and a sequence of photographs ends up being not a reaction or a recollection of images, but a relationship, an encounter between us and the space.

Another word where this meaning is etymologically contained is the French regarder, whose prefix re suggests the reiteration of this gesture, the possibility that it is not about a definitive answer but an image that builds itself through many gazes, in between who began and who will continue and, in such manner, able to change over time. In the experience of looking for everyday splendour, this shows itself to a gaze that reflects and seeks such an encounter ${ }^{23}$.

\footnotetext{
22 Martin Heidegger, Saggi e discorsi. (G. Vattimo, A cura di) (Milano: Ugo Mursia Editore, 1976), p. 96, p.125.

23 Silvano Petrosino, Lo stupore (Novara: Interlinea edizioni, 1997), p.104.
} 


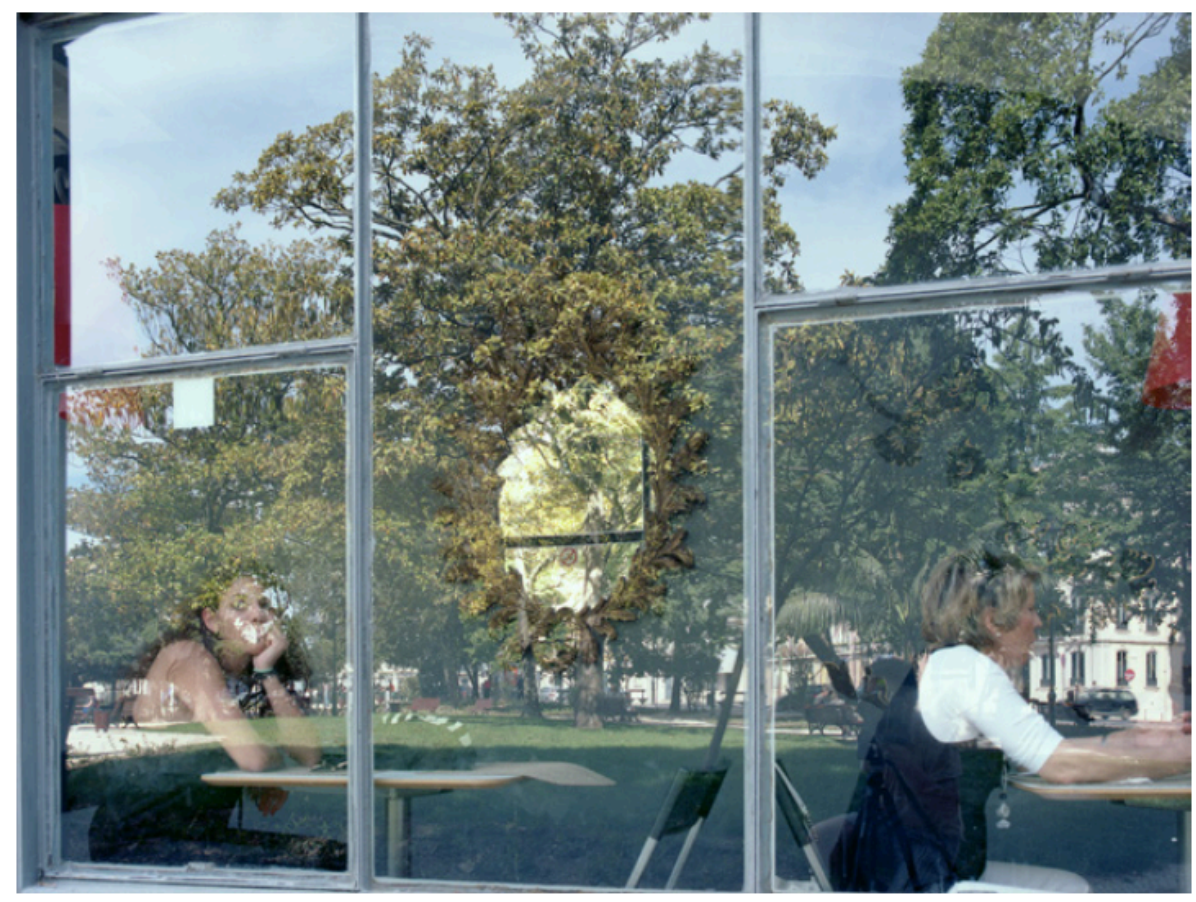

SEBASTIANO RAIMONDO

"11_191" from the series "Uma Ponte", 2009-2010

The dynamic of these reflections which I register with the camera make so that simple looking turns into seeing/keeping. Speculating, or placing the lenses' mirror between me and the world outside myself allows not only the place's manifestation but my own; as if bringing these questions upon the place and at the same time upon myself24: "why do I live here and now?" 25 Where did my experience of light take place?

\section{Along the Surface}

Throughout the continuous and accelerated mutation of the city, the most complex manifestation of mankind's inhabitancy on Earth ${ }^{26}$, one that is presented to us in countless representations by which we are influenced, what may be today the role played by the photographic surface?

Robert Adams in 1981/83 tells in his book "Beauty in Photography" that from the landscape's image something speaks to us, as much about who is behind the camera, as of what is in front of it. Behind any photographer's decision is his personal baggage of memories and reflections, his perception of the place and of similar places known before. And he adds: it is not easy to enjoy a landscape as it is, we expect the artist to give an indication in order to perceive the place's meaning. Sometimes we would rather the place itself: to perceive it, smell it, listening instead of seeing, but when we are far from that scene we expect to reencounter it somewhere else or in art. There are moments when in the photographic images we perceive the transposition of one part for another, what has been in front of the camera and us, a

\footnotetext{
24 Roland Barthes, A câmara clara - Nota sobre a fotografia. (M. Torres, Trad.) (Lisboa: Edições 70 Lda, 2015), p.91.

25 Roland Barthes, A câmara clara - Nota sobre a fotografia. (M. Torres, Trad.) (Lisboa: Edições 70 Lda, 2015), p.95.

26 Aldo Rossi, L'architettura della Città (Torino: Città Studi Edizioni, 1995), pp. 25-31.
} 
mystery made visible that gives us a feeling of comprehension, ending up by telling that maybe we believe in photography because it allows the reveal of something we already knew but that is forgotten inside us $^{27}$.

Roland Barthes called it the power of authentication that upstages the power of representation: "... the essence of photography is ratifying that which it represents ... this certainty that no text could give me ... it doesn't invent, it is the authentication itself ... not image, not reality, but truly a new being ... that which is seen on paper is as real as what is touched ... nothing can stop photography of being analogical ... the realists, among which I include and included myself when I stated that photography was an image without a code even if there are codes that come to influence its reading - the picture is not to be taken as a copy of reality, but an emanation of reality past ... questioning if the photograph is analogical or codified is not a good analysis method ... from a phenomenological point of view, in photography, the power of authentication upstages the power of representation"28. The surface of the photographic image ends up revealing only an imperfection of reality's complexity, which always presents itself as a result of all that has happened. is "precedent" communicates with us starting from the instant in which the picture is taken, it has an inheritance to measure, and a criterion of truth, through which the observed objects can be comprehended and a "so represented reality" can be communicable with simplicity and without imposition.

At last, photographs have always been and will continue to be metonymies, but at the moment in which what we see manifests and coincides with our ideas a metaphor appears. The feeling of simultaneousness between my inner space and the outer world make so that the sequence of these photographs turn themselves into the metaphor A Bridge. Through it, I summoned this city to better see it, a door built to give access and make available spaces to continue my journey, especially because I believe that bridges are built when across the margin something has been left, something that very much regards and belongs to us.

\footnotetext{
27 Robert Adams, La bellezza in fotografia - saggi in difesa dei valori tradizionali (italiana ed.). (P. C. Frongia, Trad.) (Torino: Bollati Boringhieri, 1995), pp. 7-12.

28 Roland Barthes, A câmara clara - Nota sobre a fotografia. (M. Torres, Trad.) (Lisboa: Edições 70 Lda, 2015), pp. 96-99.
} 


\section{Bibliography}

Adams, R. (1995). La bellezza in fotografia - saggi in difesa dei valori tradizionali (italiana ed.). (P. C. Frongia, Trad.) Torino: Bollati Boringhieri.

Balduzzi, M., Frongia, A., Guerrieri, W., \& Valtorta, R. (2013). Luogo e identità nella fotografia italiana contemporanea. (R. Valtorta, A cura di) Torino: Giulio Einaudi Editore.

Barthes, R. (2015). A câmara clara - Nota sobre a fotografia. (M. Torres, Trad.) Lisboa: Edições 70 Lda. Benjiamin, W. (2007). Immagini di città. Torino: Giulio Einaudi Editore.

Benjiamin, W. (2000). L'opera d'arte nell'era della sua riproducibilità tecnica - Arte e società di massa (italiana ed.). (E. Filippini, Trad.) Torino: Giulio Einaudi Editore.

Borges, J. (1982). La cifra. (D. Porzio, A cura di) Milano: Arnoldo Mondadori Editore.

Calvino, I. (1994). Palomar. Milano: Arnoldo Mondadori Editore.

Celati, G., \& Ghirri, L. (1989). II profilo delle nuvole - immagini di un paesaggio italiano. Milano: Giangiacomo Feltrinelli editore.

Chiaramonte, G. (2007). Nascosto in prospettiva. Milano: Ultreya.

De Caro, M., \& Ferraris, M. (2012). Bentornata realtà - il nuovo realismo in discussione. Torino: Giulio Einaudi Editore.

Fabiani, F., Gasparini, L., \& Sergio, G. (A cura di). (2013). Luigi Ghirri - Pensare per immagini Icone Paesaggi rchitetture. Milano: Mondadori, Electa.

Frade, P. M. (1992). Figuras do Espanto - A fotografia antes da sua cultura. Porto: Edições ASA.

Ghirri, L. (1997). Niente di antico sotto il sole. (G. Chiaramonte, \& P. Constantini, A cura di) Torino: Società Editrice Internazionale. Ghirri, L. (1989). Paesaggio italiano. Milano: Electa.

Gil, F. (1980). Enciclopedia Einaudi (Vol. XI). Torino: Einaudi.

Heidegger, M. (1976). Saggi e discorsi. (G. Vattimo, A cura di) Milano: Ugo Mursia Editore.

Mulas, U. (1973). La fotografia. Torino: Giulio Einaudi Editore.

Panofsky, E. (1961). La prospettiva come "forma simbolica" e altri scritti. (E. Filippini, Trad.) Milano: Giangiacomo Feltrinelli Editore. Pessoa, F. (1982). Livro do desassossego por Bernardo Soares (Vol. 2). Lisboa: Ática.

Petrosino, S. (1997). Lo stupore. Novara: Interlinea edizioni. 
Petrosino, S. (2004). Piccola metafisica della luce. Milano: Editoriale Jaca Book.

Purini, F. (2000). Comporre l'architettura. Roma, Bari: Gius. Laterza \& filgi.

Rossi, A. (2009). Autobiografia scientifica. Milano: Il saggiatore.

Rossi, A. (1995). L'architettura della Città. Torino: Città Studi Edizioni.

Wenders, W. (Regia). (1994). Lisbon story [Film]. Alemanha, Portugal.

Wenders, W. (Regia). (2008). Palermo Shooting [Film]. Alemanha, França, Itália.

This article is a result of the project POCI-01-0145-FEDER-030605 - PTDC/ART-OUT/30605/2017 supported by Competitiveness and Internationalisation Operational Programme (POCI), under the PORTUGAL 2020 Partnership Agreement, through the European Regional Development Fund (ERDF) and through national funds by the FCT - Fundação para a Ciência e a Tecnologia. 